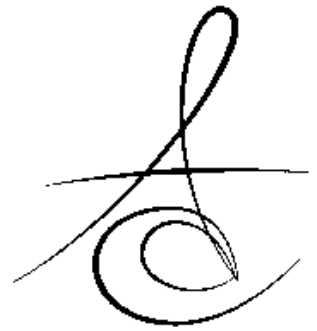

\title{
TUMOUR NECROSIS FACTOR ALPHA LEVELS IN GINGIVAL CREVICULAR FLUID OF PERIODONTITIS PATIENTS WITH/WITHOUT MTDNA DELETION IN GINGIVAL TISSUE
}

\section{GINGIVAL DOKULARINDA 5-KBP MTDNA DELESYONU OLAN VEYA OLMAYAN PERIODONTITIS HASTALARINININ DIŞETI OLUĞU SIVISINDAKI TÜMÖR NEKROZ FAKTÖRÜ ALFA SEVİYELERİ}

Makale Kodu/Article code: 1390

Makale Gönderilme tarihi; 06.11.2013

Kabul Tarihi: 28.11.2013

\section{ABSTRACT}

Aim: There are strong evidences to suggest that Tumour necrosis factor alpha (TNF-a) plays important role in the pathogenesis of destructive periodontal pathologies such as periodontitis. Excessive amounts increase reactive oxygen species (ROS) production by mitochondria, which are likely to damage cellular macromolecules, including mtDNA. The 5-kbp mtDNA deletion of gingival tissue was detected in destructive periodontal pathologies. In this study we aimed to investigate the gingival crevicular fluid (GCF) levels of TNF-a and the 5-kbp mtDNA deletion of gingival tissue in patients with periodontitis and healthy controls. Also, we examined correlations between the GCF levels of TNF-a and the 5-kbp mtDNA deletion of gingival tissue and clinical parameters of periodontitis patients.

Material and Method: The study was carried out in 64 subjects: 32 patients with chronic periodontitis (CP) and 32 periodontally healthy controls. Samples were collected from the diseased gingival tissues with $\geq 5 \mathrm{~mm}$ periodontal pockets, gingival inflammation, and bone loss during periodontal flap surgery from $\mathrm{CP}$ group and healthy gingival tissues were collected during crown lengthening procedures. TNF-a levels in GCF samples were assayed by commercial ELISA kits. Determination of the deleted mtDNA was employed a semiquantitative PCR method.

Results: All clinical parameter scores of the tissue sampling areas were significantly higher in the CP group compared to the control group. The mean GCF TNF-a level in CP group was significantly higher than that of the controls. In CP group, the mean GCF TNF-a level of patients with deleted mtDNA was significantly higher than those of patients with non-deleted mtDNA

Conclusion: According to this study findings, we speculated that overexpression of TNF- $a$, which is detected in GCF, in gingival tissue of periodontitis patients, may induces elevated ROS production in mitochondria and may lead to oxidative mitochondrial injury such as mtDNA deletion of neighboring cells.

Key Words: TNF- $a$, mtDNA deletion, gingiva, gingival crevicular fluid, destructive periodontal pathology.

\section{ÖZET}

Amaç: Tümör nekroz faktörü alfa (TNF-a) 'nın yıkıcı periodontal hastalıklardan olan periodontitisin patogenezinde önemli rolleri olduğuna dair güçlü deliller sunulmuştur. Mitokondrilerce reaktif oksijen türleri (ROT) üretiminin aşırı miktarlarda artması sonucu hücresel makromoleküllerden olan mtDNA' ya zarar verebilir. YıkıcI periodontal hastalıklarda gingival dokulardan 5-kbp mtDNA delesyonu tespit edilmiştir. $\mathrm{Bu}$ çalışmada periodontitisitli ve sağlıklı hastaların dişeti oluğu sıvısında TNF-a ve dişeti dokularında 5-kbp mtDNA delesyonunun araştırıması amaçlanmıştır. İlaveten periodontitis hastalarınının klinik parametreleri ile DOS TNF-a seviyesi ve dişeti dokularında 5-kbp mtDNA delesyonu arasındaki korelasyon durumu araştırılmıştır.

Material ve Metod: Bu çalışmaya 32 periodontal sağlıklı, 32 kronik periodontitisli (KP) olmak üzere 64 hasta dahil edildi. Hastalıklı doku numunesi KP'li gruptan $\geq 5 \mathrm{~mm}$ periodontal cebi, gingival inflamasyonu ve kemik kaybı olan hastalardan periodontal flep cerrahisi sırasında, sağlıklı dokular ise kontrol grubundan kron boyu uzatma işlemi sırasında toplandı. DOS'taki TNF-a seviyeleri ELISA kitleri ile belirlendi. mtDNA delesyonunun tespiti semikantitatif PCR metodu ile yapıldı.

Bulgular: KP grubunda doku örneklerinin alındığı bölgelerde tüm klinik parametreler kontrol grubuna göre daha yüksekti. KP grubunun DOS TNF-a seviyesi kontrol grubuna göre daha yüksekti. KP grubunda mtDNA olan hastaların DOS TNF-a seviyeleri mtDNA olmayan hastalara göre daha yüksekti.

Sonuç: Çalışmamızın sonuçlarına göre periodontitisli hastaların gingival dokularında ve DOS'ında artış gösteren TNF-a mitokondrilerde yükselen ROT üretimini indükleyebilir ve komşu hücrelerde mtDNA delesyonu gibi oksidatif mitokondriyal yaralanmalara sebebiyet verebilir.

Key Words: TNF-a, mtDNA delesyonu, gingiva, dişeti oluğu sıvıSı, yıkıcı periodontal hastalık

* Atatürk Üniversitesi, Diş Hekimliği Fakültesi, Periodontoloji Anabilim Dalı, 


\section{INTRODUCTION}

Periodontitis is an oral inflammatory disorder that gives rise to tissue damage and loss, as a result of the complex interaction between pathogenic bacteria and the host's immune response. Pathogens such as Gram-negative species, mobile rods and spirochetes may have the ability to invade gingival tissues. The

inflammatory and immuno-regulatory cytokines. ${ }^{3}$ The major sign of gingival inflammation is the presence of gingival crevicular fluid (GCF) that oozes from the gingival. The amount and rate of fluid production at a given site are highly variable and are, in a very general way, related to the severity of periodontal inflammation. GCF has been the focus of biochemical assessments for disease activity. The measure of inflammatory mediator level in the GCF has been used to evaluate risk for an individual to develop periodontal disease. Increased levels of several cytokines such as Tumour necrosis factor-alpha (TNFa) have been observed in the GCF of periodontitis patients. ${ }^{4-6}$

TNF- $a$ is a polypeptide produced by a wide variety of cell types whose production is up-regulated in a number of stressful and pathological conditions. ${ }^{7,8}$ It has been shown that TNF-a exerts an important physiological role as a modulator of immune responses by regulating specific genes needed for the host defense against a varied repertoire of agents. TNF-a appears to play a role in the control of cell cycle as DNA synthesis and cell proliferation increase in cells exposed to TNF-a, indicating that this cytokine acts as a mitogenic stimuli. ${ }^{9}$ This cytokine can also produce oxidative stress by stimulating the generation of reactive oxygen species (ROS) in inflammatory condition. TNF-a provokes a rise in hydrogen peroxide $\left(\mathrm{H}_{2} \mathrm{O}_{2}\right)$ production from mitochondria, and other ROS, via induction of NADPH oxidase, and causes cell injury by generation of oxidative stres. ${ }^{10}, 11$ Excessive amounts increase ROS production by mitochondria, which are likely to damage cellular macromolecules, including DNA.

The human mitochondrial genome is a circular, double-stranded DNA molecule composed of 16,569 based pairs. In each cell, there are a few hundred to thousands of mitochondria, and each mitochondrion contains 2-10 copies of mitochondrial DNA (mtDNA) that encodes 13 genes essential for OXPHOS, 2 ribosomal RNA (rRNA) genes and transfer RNA (tRNA) genes required for mtDNA expression. Human mtDNA is naked and is located in the vicinity of mitochondrial inner membranes, where abundant ROS and free radicals are continually generated. It is not protected by histones and replicates faster than nuclear DNA, without proofreading or efficient DNA repair systems. ${ }^{12}$ In the last decade, a number of pathogenic mutations of mtDNA, such as large-scale deletions and point mutations, have been established as responsible for or associated with several distinct human diseases. ${ }^{13}$ More than 100 large-scale deletions have been identified in various tissues of human subjects with specific mitochondrial diseases, degenerative diseases, and aging. ${ }^{14}$ These large-scale deletions often cause the removal or truncation of multiple structural genes and transfer RNA (tRNA) genes of the mitochondrial genome, which can result in multiple respiratory-chain deficiencies. Among these deletions, a 4977-bp deletion, termed the " 5 -kbp common deletion," has been identified in various diseased tissues and more recently inflamed gingival tissue. ${ }^{15,16}$

In present study, we first hypothesized that oxidative mtDNA damage of gingival tissue may be related with overexpression of inflammatory cytokines such as TNF-a in periodontitis patients. To test this hypothesis, we investigated the GCF levels of TNF-a and the 5-kbp mtDNA deletion of gingival tissue in patients with periodontitis and healthy controls. Also, we examined correlations between the GCF levels of TNF-a and the 5-kbp mtDNA deletion of gingival tissue and clinical parameters of periodontitis patients.

\section{MATERIALS AND METHODS}

Study groups

The study was carried out in 64 subjects: 32 patients with chronic periodontitis (CP) (16 males and 16 females, aged between 35 and 72 years, with a mean age of 48.7) and 32 periodontally healthy controls (16 males and 16 females, aged between 25 and 69 years, with a mean age of 45.4). The subjects were selected among the individuals who applied to Ataturk University Faculty of Dentistry, Department of Periodontology, due to periodontal problems or for routine controls. The criteria for $\mathrm{CP}$ were judged from standard measurements of clinical probing depths and radiographic bone loss according to criteria currently accepted. ${ }^{17}$ Subjects with CP had at least two sides showing probing depth $>4 \mathrm{~mm}$, gingival inflammation, 
and $30 \%$ bone loss. The control group was composed of individuals with no history of any periodontal disease, with no gingival inflammation and with good oral hygiene. The subjects included in the study: had no history of systemic disease, had not received periodontal therapy and had not taken antibiotics, anti-inflammatory drugs or any other drugs for at least 6 months, were never-smokers, not alcohol or antioxidant consumers. This study was approved by the ethics committee of Ataturk University, and a written informed consent was obtained from each participant.

Periodontal status of the tissue sampling areas in all subjects was determined by measuring plaque index (PI), ${ }^{18}$ gingival index (GI) ${ }^{19}$ probing depth (PD), and clinical attachment level (CAL). PD and CAL were measured on six sites of teeth. Full-mouth periapical radiographs were taken to determine the level of periodontal bone loss of the patients.

\section{Collection of samples}

The diseased gingival tissues with $\geq 5 \mathrm{~mm}$ periodontal pockets, gingival inflammation, and bone loss were collected during periodontal flap surgery from CP group and healthy gingival tissues were collected during crown lengthening procedures. All tissue samples were obtained from gingival margin area. Each sample was transferred in to a $50 \mathrm{ml}$ falcon tube with $10 \mathrm{ml}$ phosphate buffer solution (PBS).

GCF samples were collected from a mesiobuccal and disto-palatal site on gingival sample areas of all subjects. GCF samples were obtained before collection of gingival samples and clinical measurements, and between 08:00 and 10:00 hours in the morning. The area was isolated with cotton rolls to eliminate saliva contamination and slightly air-dried. The samples were obtained within 30s with Periopaper strips (Proflow Inc., Amityville, NY, USA) using the orifice method, and volume was measured on a precalibrated Periotrons 8000 (Oroflow Inc., Plainview, NY, USA). Care was taken to avoid mechanical injury. Strips contamined with blood were discarded.

Twenty-four strips were used for each subject. Paper strips that absorbed GCF were placed in microcentrifuge tubes containing phosphate-buffered saline (PBS) ( $\mathrm{pH} 7)$. Tubes were vortexed and centrifuged at $1500 \mathrm{Xg}$ for $10 \mathrm{~min}$. The supernatants were transferred into eppendorf tubes and stored at $80^{\circ} \mathrm{C}$ until analysis. Samples were thawed and assayed immediately to ensure minimal deterioration, and samples of each patient were assayed at the same time as the matched control samples.

\section{Laboratory analysis of TNF- $a$}

TNF-a levels in GCF samples were assayed by commercial ELISA kits (Biosource International, Camarillo, CA, USA) according to the manufacturer's instructions. Specimens were thawed and assayed immediately to ensure minimal deterioration, and each patient's samples were assayed at the same time as the matched control samples. The standards ranged from 0 to $1000 \mathrm{pg} / \mathrm{ml}$ human TNF-a.

\section{DNA extraction}

Each tissue sample underwent centrifugation for $5 \mathrm{~min}$ at $3000 \mathrm{xg}$ and supernatant removed. The pellet was re-suspended in $200 \mu \mathrm{l}$ TE Buffer and total DNA of the tissues was extracted by proteinase K/SDS lysis followed by phenol/chloroform extraction as previously described. ${ }^{15}$ After ethanol precipitation, the DNA dissolved $100 \mu \mathrm{l}$ distilled water and frozen at $30^{\circ} \mathrm{C}$ until use.

\section{Polymerase chain reaction ( $P C R$ )}

Each desired DNA fragment was amplified in $50 \mu \mathrm{l}$ reaction mixture containing $16 \mu \mathrm{l}$ DNA $(1 \mu \mathrm{g} / 50 \mu \mathrm{l})$, $1.5 \mu \mathrm{l}$ deoxynucleotide triphosphate (0.2mM) (Fermentas, Germany), $1.5 \mu$ l of each primer $(1 \mu \mathrm{M})$, $1.5 \mu \mathrm{l}$ Taq DNA polymerase $(5 \mathrm{u} / 50 \mu \mathrm{l})$ (Fermentas, Germany), $3 \mu \mathrm{l} \mathrm{MgCl}_{2}(4 \mathrm{mM} / 50 \mu \mathrm{l}), 5 \mu \mathrm{l} 10 \mathrm{XPCR}$ buffer (Fermentas, Germany) (without magnesium) and $20 \mu \mathrm{l}$ sterilized water. The reactions were carried out for 30 cycles in a Sanyo DNA Amplifier thermal cycler (MIRD30, Sanyo, Japan) PCR cycles consisted of $25 \mathrm{~s}$ denaturation at $94{ }^{\circ} \mathrm{C}, 25 \mathrm{~s}$ annealing at $50^{\circ} \mathrm{C}$ and $80 \mathrm{~s}$ primer extension at $72{ }^{\circ} \mathrm{C}$. The PCR products were separated on a $1.5 \%$ agarose gel at $110 \mathrm{~V}$ for $40 \mathrm{~min}$ and were detected fluorographically after staining with $0.5 \mu \mathrm{g} / \mathrm{ml}$ ethidium bromide (Sigma-Aldrich, Germany). The gel patterns of the PCR products were photographed under UV transillumination (Syngene, U.K).

Determination of the proportion of deleted $m t D N A$

For determination of the deleted mtDNA, we employed a semiquantitative PCR method as previously described. ${ }^{14}$ Each of the mtDNA samples was serially diluted by two-fold with distilled water before PCR amplication. The range of dilution was usually between $2^{0}$ and $2^{22}$. The two different pairs of PCR primers (Thermo Electron Corp., US) were used in this study. 
The primers L[6251]5'-TATAGTGGAGGCCGGAGCAG$3^{\prime}$ and H[7261]5'-GAATGAGCCTACAGATGATA-3' were used for amplication of a $1.0 \mathrm{kbp}$ DNA fragment from the total mtDNA. The primers $L[6251]$ and $H[7261]$ were used for proving of DNA extraction and of PCR procedures. We used the primers L[7901]5'TGAACCTACGAGTACACCGA-3' and H[13631]5'GGGGAAGCGAGGTTGACC TG-3' for amplication of a $0.8 \mathrm{kbp}$ PCR product from the $5 \mathrm{kbp}$ deleted mtDNA. In addition, DNA ladders (GeneRuler 100-bp DNA ladder, Fermentas) were used for determination of DNA fragment size.

\section{Statistical Analyses}

Differences in clinical parameters between controls and chronic periodontitis groups were analyzed by an unpaired $t$ test. Differences in the GCF TNF-a level between controls and chronic periodontitis groups were analyzed by Mann-Whitney $U$ test. Correlation between the GCF TNF-a level, clinical parameters and the presence of mtDNA deletion were analyzed by the Spearman rank correlation test. All statistical analyses were performed using statistical software (SPSS 13.0 for Windows, US).

\section{RESULTS}

\section{Clinical Findings}

The median values of the clinical parameter are shown in Table 1. All clinical parameter scores of the tissue sampling areas were significantly higher in the CP group compared to the control group $(p<0.001)$ (Table 1). There was no significant difference between the mean ages of the two groups ( $p>0.05)$ (Table 1$)$.

Table 1. Clinical parameters of the groups (mean $\pm S D$ ).

\begin{tabular}{|l|l|l|}
\hline & Controls & CP group \\
\hline $\mathbf{N}$ & 32 & 32 \\
\hline Age & $45.4 \pm 11,9$ & $48.7 \pm 9.3$ \\
\hline PI & $0.78 \pm 0.41$ & $1.81 \pm 0.52^{*}$ \\
\hline GI & $0.61 \pm 0.37$ & $1.76 \pm 0.43^{*}$ \\
\hline PD(mm) & $2.03 \pm 0.45$ & $4.33 \pm 0.78^{*}$ \\
\hline CAL(mm) & $0.00 \pm 0.00$ & $4.62 \pm 1.01^{*}$ \\
\hline
\end{tabular}

$* p<0.001$ Difference is significant.

$\mathrm{N}$-number of subjects, PI-plaque index, GI-gingival index, PD-probing depth, CAL-clinical attachment level

\section{Laboratory Findings}

The 5-kbp mtDNA deletion was observed in 20 of the 32 periodontitis patients and was not detected in the controls (Table 2) (Figure 1). This result demonstrates that the frequency of occurrence of the 5-kbp mtDNA deletion in chronic periodontitis group was $62.5 \%$.

The mean GCF TNF-a level in chronic periodontitis group $(8,59 \pm 4.30 \mathrm{pg} / \mathrm{ml})$ was significantly higher $(P<0.01)$ than that of the controls $(1.64 \pm 0.72 \mathrm{pg} / \mathrm{ml})$. In chronic periodontitis group, the mean GCF TNF-a level of patients with deleted mtDNA $(11,03 \pm 3,43$ $\mathrm{pg} / \mathrm{ml}$ ) was significantly higher than those of patients with non-deleted mtDNA $(4,51 \pm 2,03 \mathrm{pg} / \mathrm{ml})$ $(P<0.01)$ (Figure 2).

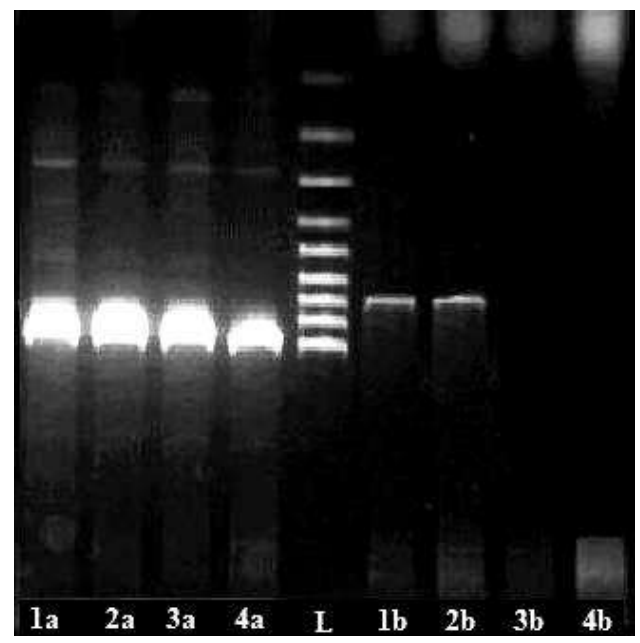

Figure 1. A photograph of $1.5 \%$ agarose gel belongs to four patients with chronic periodontitis (patient numbers: 1, 2, 3, 4). L: 100 bp DNA ladder. The mtDNA extraction and PCR protocol are confirmed by using controls $(\approx 1.0 \mathrm{kbp}$ fragments at lanes of $1 \mathrm{a}, 2 \mathrm{a}, 3 \mathrm{a}$ and $4 \mathrm{a})$. The $5 \mathrm{kp} \mathrm{mtDNA}$ deletions are detected in 2 of the 4 patients. $(\approx 0.8 \mathrm{kbp}$ fragments at lanes of $1 \mathrm{~b}$ and $2 \mathrm{~b}$ ).

We evaluated the relationships among the occurrence of the 5-kbp mtDNA deletion, clinical parameters (PI, GI, PD, CAL and age), and the GCF TNF-a levels in CP group. Statistically significant positive correlations were observed between the occurrence of the 5-kbp mtDNA deletion, and age, PD and CAL. Similarly, the GCF TNF-a levels were correlated with age, PD and CAL $(p<0.01, p<0.05)$ (Table 3). Additionally, a positive correlation was found between the occurrence of the 5-kbp mtDNA deletion and the GCF TNF-a levels $(p<0.01)$ (Table 3$)$.

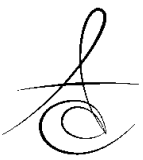




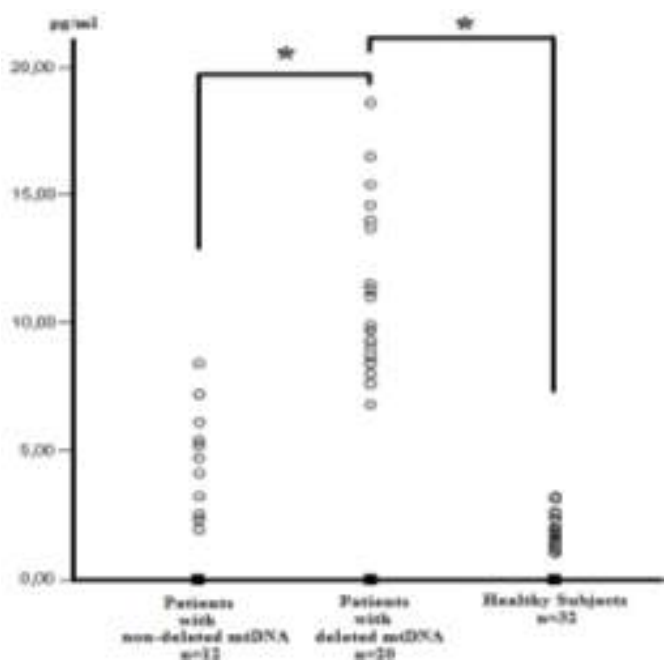

Figure 2. Distribution of the GCF TNF-a levels from periodontitis patients and healthy subjects. The periodontitis patients were divided into two subgroups, based on the presence/absence of mtDNA deletion in gingival tissues. The Correlation of the 5-kbp mtDNA deletion with clinical parameters and the GCF TNF-a level in the chronic periodontitis group

Table 2. MtDNA deletions of the groups. ( $\mathrm{n} \%$ )

\begin{tabular}{|l|l|l|l|l|l|l|}
\hline & $\begin{array}{l}\text { mtDNA } \\
\text { deletion }\end{array}$ & GI & PI & PD & CAL & Age \\
\hline $\begin{array}{l}\text { GCF } \\
\text { TNF-a }\end{array}$ & $0.801^{\dagger}$ & 0.103 & 0.163 & $0.635^{\dagger}$ & $0.536^{\dagger}$ & $0.398^{*}$ \\
\hline $\begin{array}{l}\text { mtDNA } \\
\text { deletion }\end{array}$ & - & -0.085 & 0.005 & $0.493^{\dagger}$ & $0.512^{\dagger}$ & $0.372^{*}$ \\
\hline
\end{tabular}

PCR was performed by use of two primer pairs for three regions (Control Region and $5 \mathrm{kbp}$ deletion Region) as described in Materials and Methods. Primer pair of $\mathrm{L}[6251], \mathrm{H}[7261]$ were used for amplication of a $1.0 \mathrm{kbp}$ DNA fragment from the total mtDNA and used for proving of DNA extraction and of PCR procedures. In CP and Control groups, aproximately $1.0 \mathrm{kbp}$ DNA fragment was observed in all individuals $(32(+) \% 100$ in both group). Primer pair of $\mathrm{L}$ [7901], $\mathrm{H}[13631]$ were used for amplication of a $0.8 \mathrm{kbp}$ DNA fragment from the total mtDNA and used for determination of $5 \mathrm{kbp}$ deletion. In CP group, aproximately $0.8 \mathrm{kbp}$ DNA fragment was observed in 20 of the 32 subjects (20(+) \%62.5 and $12(-) \% 37.5)$. In Controls, aproximately $0.8 \mathrm{kbp}$ DNA fragment was not observed (32(-) \%100).(CPchronic periodontitis).
Table 3. Correlation between the salivary 8-OHdG level and mtDNA deletion of gingival tissue and clinical parameters of periodontitis in $\mathrm{CP}$ group.

\begin{tabular}{|l|l|l|}
\hline & Control Region & $\begin{array}{l}\text { 5 kbp deletion } \\
\text { Region }\end{array}$ \\
\hline Primers & $\mathrm{L}[6251], \mathrm{H}[7261]$ & $\mathrm{L}[7901], \mathrm{H}[13631]$ \\
\hline Fragment & $\approx 1.0 \mathrm{kbp}$ & $\approx 0.8 \mathrm{kbp}$ \\
\hline Controls & $32(+) \% 100$ & $0(+) \% 0$ \\
& $0(-) \% 0$ & $32(-) \% 100$ \\
\hline CP group & $32(+) \% 100$ & $20(+) \% 62.5$ \\
& $0(-) \% 0$ & $12(-) \% 37.5$ \\
\hline
\end{tabular}

* Correlation is significant $(p<0.05)$.

+ Correlation is significant $(p<0.01)$.

PI-plaque index, GI-gingival index, PD-probing depth, CALclinical attachment level

\section{DISCUSSION}

Despite a growing number of investigations dealing mainly with immunomodulatory activities of TNF-a, its mechanism of cytotoxicity is still largely unknown in especially periodontal pathologies. Previously, a number of studies have demonstrated that oxidative stress involving generation of ROS is responsible for the cytotoxic action of TNF-a overexpression $^{10,11,20,21}$. Different form of DNA damage such as fragmentation and deletion were shown to be induced by TNF-a ${ }^{22,23}$. Also, TNF-a induced oxidative DNA damage biomarker (8-OHdG) have been reported in previous studies ${ }^{24}$.

In present study, we measured the GCF TNF-a level and examined the 5-kbp mtDNA deletion of gingival tissues in periodontitis patients and healthy controls. Our study showed that the GCF TNF-a levels were significantly higher in periodontitis patients than healthy controls. In previous periodontal studies it was indicated that TNF-a can reach high concentration in the diseased gingival tissue and reported the higher levels of TNF-a in the GCF of periodontitis patients ${ }^{4-6 \text {, }}$ 25. Our result confirms findings of these previous studies. Also, we detected the 5-kbp mtDNA deletion in gingival tissues of 20 of 32 periodontitis patients and did not detect in healthy controls. Two studies carried out by our research group ${ }^{15}$ and Sugano et al. ${ }^{16}$ reported the 5 -kbp mtDNA deletion in gingival of periodontitis patients. Our result parallels with the result of these previous studies. Notably, we first determined that the GCF TNF-a level of periodontitis

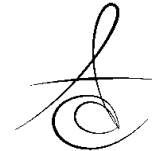


patients with deleted mtDNA were significantly higher than those of patients with non-deleted mtDNA, and a positive correlation between the GCF TNF-a levels and the occurrence of the 5-kbp mtDNA deletion in diseased gingival tissues. That TNF-a causes oxidative injury to mitochondria is well established. SchulzeOsthoff et al. ${ }^{26}$ showed in vitro that TNF-a interfered with mitochondrial structures. Authors concluded the TNF-induced inhibition of the mitochondrial electron transport, together with the effects observed for different mitochondrial inhibitors, favor the explanation that TNF damages the mitochondrial chain at complex III, which consequently result in the increased production of oxygen radicals inside the mitochondria. Similarly, Hennet et al. ${ }^{21}$ concluded that TNF-a induces elevated superoxide $\left(\mathrm{O}_{2}{ }^{-}\right)$production in mitochondria and authors also reminded the mitochondria has no DNA repair system, rendering mtDNA very susceptible to oxidative damage. Nagakawa et al. ${ }^{27}$ investigated the role of TNF-a on mtDNA damage and deletion in hepatocytes of rejecting liver allograft. Authors described the excessive ROS production and morphological injury in mitochondria after TNF-a exposure, and demonstrated that TNF-a causes mtDNA damage and deletion in hepatocytes. In present study, the higher GCF TNF-a level in periodontitis patients with mtDNA deletion in gingival tissue demonstrated the higher disease activity and the higher TNF-a production in gingival tissue of these patients. This result of our study do not provide direct evidence for TNF-a-induced mtDNA damage, but may be first finding about possible effect of TNF-a overproduction on mitochondrial structures such as mtDNA in gingival tissue of periodontitis patients.

On the other hand, we found that both the GCF TNF-a levels and the occurrence of the 5-kbp mtDNA deletion had significant positive correlations with age, PD and CAL, and no significant correlations with PI and GI in periodontitis group. Generally, agedependent oxidative mtDNA damages have been detected previously in liver ${ }^{28}$, testis, ${ }^{14}$ muscle, ${ }^{29}$ heart, ${ }^{30}$ and lung ${ }^{31}$ tissues of healthy elderly subjects. Lim et al. ${ }^{29}$ clearly demonstrated that the frequency of oxidative mtDNA damage in human skeletal muscle of end stage renal disease (ESRD) patients was higher than those of age-matched non-ESRD subjects and the increase of oxidative stress may lead to premature oxidative damage of the mitochondrial genome in diseased tissues. Suzuki et al. ${ }^{32}$ reported that the mtDNA deletion is correlated not only with age but also with the duration of disease. In our previous study ${ }^{15}$ and this study, we reported that the mtDNA deletion in gingival tissues of healthy subjects in the age group $<70$ years are not found. If so, age factor may be related with the period of disease in periodontitis patients. Similarly, the positive correlations between the occurrence of mtDNA deletion and clinical parameters (PD and CAL), and between the GCF TNF- $a$ levels and clinical parameters (PD and $\mathrm{CAL}$ ) may be related with the duration of periodontitis and indirectly disease severity, because the long-term stimulation of cytokines such as TNF-a provokes both extracellular overproduction of ROS by PMN activation and a rise in ROS production from mitochondria. This hypothesis coheres with the characteristic of $\mathrm{CP}$.

In conclusion, we first time investigated the GCF TNF-a levels in periodontitis patients with/without mtDNA deletion in gingival tissue. According to this study findings, we speculated that overexpression of TNF-a, which is detected in GCF, in gingival tissue of periodontitis patients, may induces elevated ROS production in mitochondria and may lead to oxidative mitochondrial injury such as mtDNA deletion of neighboring cells. However, further investigations are needed to clarify the exact mechanism of TNF-ainduced oxidative mtDNA damage in diseased periodontium.

\section{REFERENCES}

1. Genco RJ, Zambon JJ, Christersson LA. The origin of periodontal infections. Adv Dent Res 1988; 2: 245-59.

2. Özcan E, Özdemir A, Çanakçı CF. The Role Of Reactive Oxygen Species In Periodontal Tissue Destruction. J Dent Fac Atatürk Uni 2011; 21: 255-61.

3. Genco RJ. Host responses in periodontal diseases: current concepts. J Periodontol 1992; 63: 338-55.

4. Hirose K, Isogai E, Miura H, Ueda I. Levels of Porphyromonas gingivalis Fimbriae and inflammatory cytokines in gingival crevicular fluid from adult human subjects. Microbiol Immunol 1997; 41: 21-6. 
5. Lee HJ, Kang IK, Chung CP, Choi SM. The subgingival microflora and gingival crevicular fluid cytokines in refractory periodontitis. J Clin Periodontol 1995; 22: 885-90.

6. Rossomando EF, Kennedy JE, Hadjimichael J. Tumour necrosis factor alpha in gingival crevicular fluid as a possible indicator of periodontal disease in humans. Arch Oral Biol 1990; 35: 431-4.

7. Beutler B, Cerami A. Cachectin and tumour necrosis factor as two sides of the same biological coin. Nature 1986; 320: 584-8.

8. Fiers W. Tumor necrosis factor. Characterization at the molecular, cellular and in vivo level. FEBS Lett 1991; 285: 199-212.

9. Feingold KR, Soued M, Grunfeld C. Tumor necrosis factor stimulates DNA synthesis in the liver of intact rats. Biochem Biophys Res Commun 1988; 153: 576-82.

10. Garcia-Ruiz C, Colell A, Mari M, Morales A, Fernandez-Checa JC. Direct effect of ceramide on the mitochondrial electron transport chain leads to generation of reactive oxygen species. Role of mitochondrial glutathione. J Biol Chem 1997; 272: 11369-77.

11. Lo YY, Cruz TF. Involvement of reactive oxygen species in cytokine and growth factor induction of c-fos expression in chondrocytes. J Biol Chem 1995; 270: 11727-30.

12. Yakes FM, Van Houten B. Mitochondrial DNA damage is more extensive and persists longer than nuclear DNA damage in human cells following oxidative stress. Proc Natl Acad Sci U S A 1997; 94: 514-9.

13. Wallace DC, Shoffner JM, Trounce I, Brown MD, Ballinger SW, Corral-Debrinski M, Horton T, Jun AS, Lott MT. Mitochondrial DNA mutations in human degenerative diseases and aging. Biochim Biophys Acta 1995; 1271: 141-51.

14. Lee HC, Pang CY, Hsu HS, Wei YH. Differential accumulations of 4,977 bp deletion in mitochondrial DNA of various tissues in human ageing. Biochim Biophys Acta 1994; 1226: 37-43.

15. Canakci CF, Tatar A, Canakci V, Cicek Y, Oztas S, Orbak R. New evidence of premature oxidative DNA damage: mitochondrial DNA deletion in gingival tissue of patients with periodontitis. J Periodontol 2006; 77: 1894-900.
16. Sugano N, Kawamoto K, Numazaki H, Murai S, Ito $\mathrm{K}$. Detection of mitochondrial DNA mutations in human gingival tissues. J Oral Sci 2000; 42: 221-3.

17. Armitage GC. Development of a classification system for periodontal diseases and conditions. Ann Periodontol 1999; 4: 1-6.

18. Silness J, Loe H. Periodontal Disease in Pregnancy. Ii. Correlation between Oral Hygiene and Periodontal Condtion. Acta Odontol Scand 1964; 22: 121-35.

19. Loe H, Silness J. Periodontal Disease in Pregnancy. I. Prevalence and Severity. Acta Odontol Scand 1963; 21: 533-51.

20. Morales A, Garcia-Ruiz C, Miranda M, Mari M, Colell A, Ardite E, Fernandez-Checa JC. Tumor necrosis factor increases hepatocellular glutathione by transcriptional regulation of the heavy subunit chain of gamma-glutamylcysteine synthetase. ] Biol Chem 1997; 272: 30371-9.

21. Hennet T, Richter C, Peterhans E. Tumour necrosis factor-alpha induces superoxide anion generation in mitochondria of L929 cells. Biochem J 1993; 289: 587-92.

22. Rubin BY, Smith L], Hellermann GR, Lunn RM, Richardson NK, Anderson SL. Correlation between the anticellular and DNA fragmenting activities of tumor necrosis factor. Cancer Res 1988; 48: 600610.

23. Zimmerman RJ, Chan A, Leadon SA. Oxidative damage in murine tumor cells treated in vitro by recombinant human tumor necrosis factor. Cancer Res 1989; 49: 1644-8.

24. Park YM, Han MY, Blackburn RV, Lee YJ. Overexpression of HSP25 reduces the level of TNF alpha-induced oxidative DNA damage biomarker, 8-hydroxy-2'-deoxyguanosine, in L929 cells. J Cell Physiol 1998; 174: 27-34.

25. Canakci V, Canakci CF, Yildirim A, Ingec M, Eltas A, Erturk A. Periodontal disease increases the risk of severe pre-eclampsia among pregnant women. J Clin Periodontol 2007; 34: 639-45.

26. Schulze-Osthoff $K$, Bakker AC, Vanhaesebroeck $B$, Beyaert R, Jacob WA, Fiers W. Cytotoxic activity of tumor necrosis factor is mediated by early damage of mitochondrial functions. Evidence for the involvement of mitochondrial radical generation. J Biol Chem 1992; 267: 5317-23. 
27. Nagakawa Y, Williams GM, Zheng Q, Tsuchida A, Aoki T, Montgomery RA, Klein AS, Sun Z. Oxidative mitochondrial DNA damage and deletion in hepatocytes of rejecting liver allografts in rats: role of TNF-alpha. Hepatology 2005; 42: 208-15.

28. Yen TC, Su JH, King KL, Wei YH. Ageing-associated $5 \mathrm{~kb}$ deletion in human liver mitochondrial DNA. Biochem Biophys Res Commun 1991; 178: 124-31.

29. Lim PS, Cheng YM, Wei YH. Large-scale mitochondrial DNA deletions in skeletal muscle of patients with end-stage renal disease. Free Radic Biol Med 2000; 29: 454-63.

30. Katsumata K, Hayakawa M, Tanaka M, Sugiyama $S$, Ozawa T. Fragmentation of human heart mitochondrial DNA associated with premature aging. Biochem Biophys Res Commun 1994; 202: 102-10.

31. Lee HC, Lim ML, Lu CY, Liu VW, Fahn HJ, Zhang C, Nagley $\mathrm{P}$, Wei $\mathrm{YH}$. Concurrent increase of oxidative DNA damage and lipid peroxidation together with mitochondrial DNA mutation in human lung tissues during aging--smoking enhances oxidative stress on the aged tissues. Arch Biochem Biophys 1999; 362: 309-16.

32. Suzuki S, Hinokio Y, Komatu K, Ohtomo M, Onoda M, Hirai S, Hirai M, Hirai A, Chiba M, Kasuga S, Akai $\mathrm{H}$, Toyota $\mathrm{T}$. Oxidative damage to mitochondrial DNA and its relationship to diabetic complications. Diabetes Res Clin Pract 1999; 45: 161-8.

\section{Yazışma Adresi:}

Gülnihal Emrem DOĞAN

Atatürk University

Faculty of Dentistry

Department of Periodontology

Fax: +904422360945

25240 Erzurum/TURKEY

E-mail: gulnihalemrem@hotmail.com 